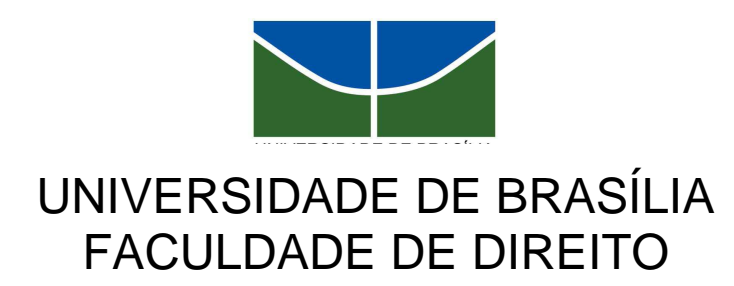

ARTHUR LUIS PINHO DE LIMA

CIDADANIA FISCAL E O PROGRAMA NOTA LEGAL 
UNIVERSIDADE DE BRASÍLIA

FACULDADE DE DIREITO

ARTHUR LUIS PINHO DE LIMA

\title{
CIDADANIA FISCAL E O PROGRAMA NOTA LEGAL
}

\begin{abstract}
Trabalho de conclusão de curso apresentado à Banca Examinadora da Faculdade de Direito da Universidade de Brasília como requisito parcial para a obtenção do título de Bacharel em Direito.
\end{abstract}

Orientador: Prof. Dr. Antônio de Moura Borges 
Lima, Arthur Luis Pinho de.

Cidadania Fiscal e o Programa Nota Legal / Arthur Luis Pinho de Lima. Brasília, 2011.

Trabalho de Conclusão de Curso - Universidade de Brasília, Faculdade de Direito, 2011.

Orientador: Prof Dr Antonio de Moura Borges.

1. Direito Tributário 2. Cidadania Fiscal 3 Programas de Incentivo Fiscal 4. Tributos 


\title{
Cidadania Fiscal e o Programa Nota Legal
}

\author{
Arthur Luis Pinho de Lima
}

BANCA EXAMINADORA

Prof. Dr. Antônio de Moura Borges

Orientador

Prof. Dr. Marcos Aurélio Pereira Valadão Membro

Prof. Dr. Maurin Almeida Falcão

Membro 


\section{RESUMO}

O aumento da carga tributária num país que serviços públicos não são condizentes com o recurso arrecadado por meio dos tributos. Destaca-se o incentivo da participação política das pessoas contra a elevada carga tributária que serve para manter um país pesado. O modelo de tributação altamente concentrador de renda no Brasil. Quebra de paradigma na relação contribuinte versus fisco. Cliente versus fornecedor de políticas públicas. A cidadania como participação política. A limitação da capacidade de investimento como resultado da pesada carga tributária. A necessidade de pesquisar o impacto dos programas de incentivo fiscal, em especial o Programa Nota Legal, na renda da população economicamente ativa e a avaliação da possibilidade de ampliar o programa pesquisado para que alcance um maior número de pessoas. Os principais tributos, sobre o consumo, envolvidos nos programas de incentivo. Os principais tributos, sobre o patrimônio, envolvidos nos programas de incentivo fiscal. Os programas de incentivo fiscal. O programa Nota Legal. A pesquisa, o resultado e a discussão do questionário aplicado aos possíveis usuários do Programa Nota Legal. A confirmação do sentimento popular da pesada carga tributária.

Palavras-chave: Tributos. Cidadania Fiscal. Programas de incentivo fiscal. Programa Nota Legal. 


\section{RESUMEN}

El aumento de la carga tributaria en un país que los servicios públicos no son congruentes con los fondos recaudados a través de impuestos. Es de destacar el fomento de la participación política de las personas de la elevada presión fiscal que sirve para mantener un país fuerte. El modelo de alta concentración de impuesto sobre la renta en Brasil. Quebra de paradigma en la relación de los contribuyentes frente al impuesto. Se convierte em un cliente frente a proveedores de las políticas públicas. La ciudadanía como participación política. La limitación de la inversión como resultado de la pesada carga fiscal. La necesidad de investigar el impacto de los programas de incentivos fiscales, en particular el Programa "Nota Legal", en los ingresos de la población económicamente activa y la evaluación de la posibilidad de ampliar el programa. Los principales impuestos en el consumo participan en programas de incentivos. Los principales impuestos sobre los activos involucrados en los programas de incentivo fiscal. Los programas de incentivos fiscales. El programa "Nota Legal". Los resultados del estudio y discusión del cuestionario aplicado a los usuarios potenciales de la renuncia del Programa. La confirmación del sentimiento popular de la pesada carga fiscal.

Palabras clave: Impuestos. La ciudadanía fiscal. Programas de incentivos fiscales. Programa "Nota Legal". 
RESUMO

RESUMEN

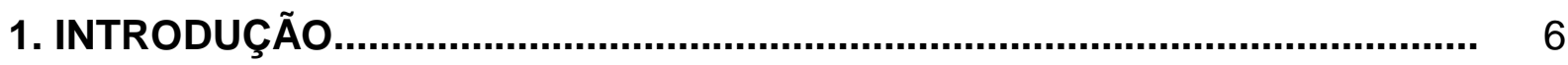

2. OS TRIBUTOS E OS PROGRAMAS DE DIMINUIÇÃO DA CARGA

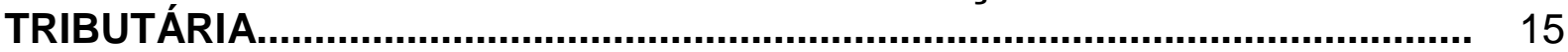

2.1 Principais tributos, sobre o consumo, envolvidos nos programas de incentivo

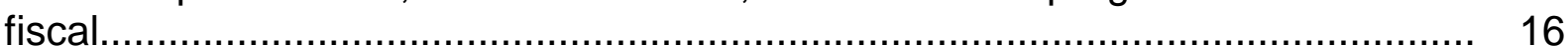
2.2 Principais tributos, sobre o patrimônio, envolvidos nos programas de incentivo fiscal.

2.3 Programas de incentivo fiscal............................................................. 27

3. A PESQUISA, O RESULTADO E DISCUSSÃO............................................ 34

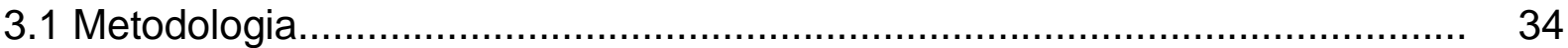

3.2 Resultados e Discussão........................................................................ 34

4. CONSIDERAÇÕES FINAIS..................................................................... 39

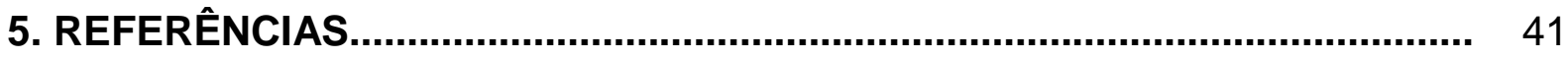

ANEXOS

ANEXO A - Questionário aplicado aos possíveis usuários do Programa Nota Legal

ANEXO B - TOTAL DA RECEITA

ANEXO C - TOTAL DA RECEITA X RECEITAS TRIBUTÁRIAS

ANEXO D - QUADRO DEMONSTRATIVO DA RECEITA ARRECADADA CONSOLIDADE - GDF 
1. INTRODUÇÃO

"The power to tax involves the power to destroy"1

A participação política das pessoas não fica adstrita apenas ao voto. É um círculo virtuoso, às vezes vicioso, a busca pelo conhecimento do significado das palavras usadas muitas das vezes sem tradução para a prática. Participação política, cidadãos, cidadania, cidadania fiscal são conceitos que traduzem a busca por parte da sociedade pelo Estado Social que tem o dever de providenciar uma diminuição dos contrastes sociais com os recursos coletados do seu povo.

Essa participação política, muita das vezes entendida como o exercício do voto, pode ser ampliada para a efetiva participação do cidadão na condução dos destinos da nação.

Ainda, ela se traduz no direito de ser ouvido e no dever de opinar sobre o destino dos tributos arrecadados.

Este cidadão vive hoje em dia com a ideia de que os tributos não se destinam ao fim desejado. A elevada carga tributária serve apenas para manter um Estado pesado.

É bem verdade que a maioria da população desconhece as alíquotas ${ }^{2}$ embutidas nos preços das mercadorias e dos serviços. Despertar a consciência fiscal, como forma de conhecer o quanto se paga de imposto e o sacrifício realizado para a manutenção dos serviços públicos, deve ser um dos objetivos de um Estado Democrático de Direito ${ }^{3}$.

Baleeiro, citado por Barbosa (2005, p.68), chama este comportamento de anestesia fiscal. Os impostos sobre a venda e serviços são regressivos ou inversamente progressivos, isto é, retiram aos pobres maior percentagem de recursos do que aos ricos, já que os artigos de alimentação e vestuário absorvem a

\footnotetext{
${ }^{1}$ O poder de tributar envolve o poder de destruir.

${ }^{2}$ Percentual ou valor fixo que será aplicado sobre a base de cálculo para o cálculo do valor de um tributo. A alíquota será um percentual quando a base de cálculo for um valor econômico, e será um valor quando a base de cálculo for uma unidade não monetária. As alíquotas em percentual são mais comuns em impostos e as alíquotas em valor ocorrem mais em tributos como empréstimo compulsório, taxas e contribuição de melhoria.

${ }^{3}$ Padre Antonio Vieira conseguiu resumir a importância de se conhecer os tributos cobrados num sermão que versou sobre o primeiro imposto de um Estado Moderno, em 1642, perante o Rei e a Corte de Portugal: ...Assim aconteceu aos bem governados vassalos do imperador Teodorico, dos quais por grande glória sua dizia ele: Sentimus auctas illationes, vos addita tributa nescitis: Eu sei que há tributos, porque vejo as minhas rendas acrescentadas; vós não sabeis se os há, porque não sentis as vossas diminuída (Barbosa, p. 69).
} 
quase totalidade dos salários e apenas pequena parte dos altos rendimentos das classes abastadas.

Ainda, um escritor espanhol, Gonzalo Higuera, citado por Vives (2005, p. 94) afirma que: "La progresividad debe ser efectiva, real. No sólo en el articulado de las disposiciones tributarias. Porque, en muchas circunstancias, se produce el hecho de que impuestos o sistemas teóricamente progresivos, en realidad, por inesperadas traslaciones o repercusiones, concluyen transformados en acusada imposición indireta y regresiva sobre capacidades económicas que rondan o están ya por debajo del mínimo vital, pagados, además, por sujetos fiscales muy distintos de los que pensó el legislador y distorsionan el espíritu y hasta la letra de la disposición legal promulgada”.

Essa translação é definida por Vives (2005, p. 95) como: "Es el fenómeno por el cual el contribuyente de derecho, el designado por la ley, para pagar el tributo, consigue transferir la carga sobre otro, que se denomina contribuyente de hecho, porque es el que realmente lo paga".

Em matéria de transparência e translação fiscal, o melhor exemplo dentro do imposto sobre o consumo cabe aos Estados Unidos da América. Nesse País, o preço das mercadorias à venda nas lojas é fixado pelo seu valor de custo. Ao final da transação, o valor do imposto é cobrado à parte na nota fiscal. No estado da Flórida, o valor do imposto é de $6 \%$ sobre o total da compra de vestuário, assim o contribuinte sabe perfeitamente quanto custa o produto e quanto o Estado cobra de imposto. Não existe tal praticidade no cálculo do imposto sobre uma compra de roupa no Brasil.

Por outro lado, o cidadão busca qualidade de vida. Pode-se afirmar que a qualidade de vida do cidadão passa pela melhoria do emprego dos recursos públicos colocados a disposição da sociedade através da obrigatória contribuição dos cidadãos pagantes.

Uma das formas de se perceber a busca ou não dessa qualidade de vida dos cidadãos pode ser aferida com os gastos na educação. Grande parte do orçamento do governo se direciona ao ensino superior, havendo poucos recursos para os demais níveis da educação, o que leva a distorções sociais relevantes. Calcula-se que cerca de $46 \%$ dos recursos da União para o ensino superior beneficiam apenas indivíduos que se encontram entre os $10 \%$ mais ricos da 
população. De todo modo, na última década, o acesso ao ensino fundamental no Brasil melhorou e ajudou a reduzir a desigualdade educacional ${ }^{4}$.

Um artigo publicado por José Márcio Camargo relata que, pelo fato das famílias pobres se depararem com essa baixa qualidade do ensino, elas tenderiam a dar pouca atenção à educação dos filhos. O menor investimento no capital humano dos filhos pelas famílias mais pobres pode criar um círculo vicioso, pois como esta decisão implica a permanência da pobreza dos filhos no futuro, dado a baixa qualidade da mão-de-obra (consequentemente dos salários), ao lidarem com o mesmo problema, tenderiam a tomar a mesma decisão sobre seus filhos, perpetuando assim a pobreza ${ }^{5}$.

Ainda, o modelo de tributação no Brasil é altamente concentrador de renda. Isso porque o Estado cobra impostos de todos, inclusive, e até principalmente, dos muito pobres, tributação indireta regressiva, que incide sobre os bens de consumo popular e da classe média, que são fortemente tributados ${ }^{6}$.

\section{Brasil: Carga Tributária (\%) por Décimos de Renda, 2002-2003, a partir da POF}

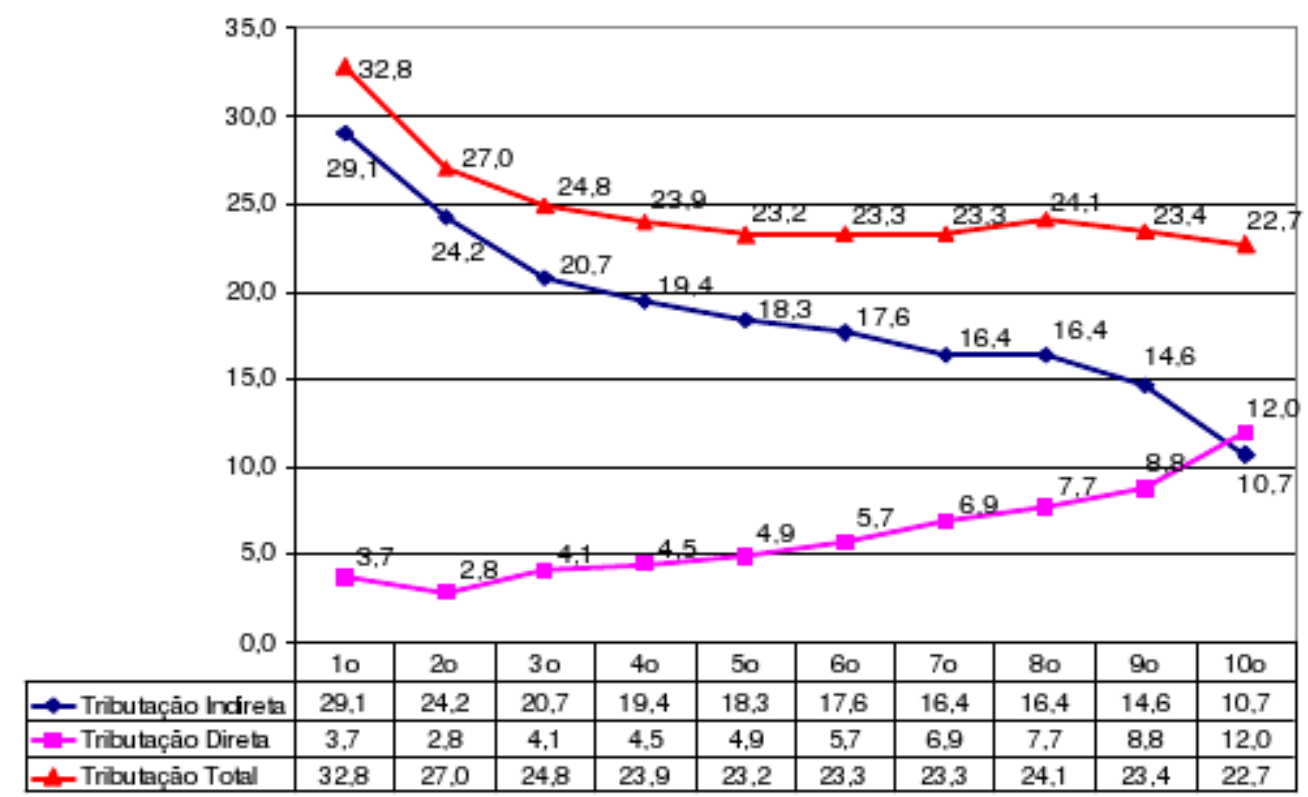

Fonte: POF/IBGE (microdados). Elaboração: IPEA, a partir de GAIGER, 2008.

Figura 1 - Carga Tributária por Décimos de Rendas

\footnotetext{
${ }^{4}$ Ministério da Fazenda - Gasto Social do Governo Central, 2001-2002, Brasília, 2003.

${ }^{5}$ Almeida, H. e J.M. Camargo, Human Capital Investment and Poverty, Texto para Discussão n. 319 , Departamento de Economia, PUC/Rio, 1994.

${ }^{6}$ POCHMAN, Márcio.Desigualdade e Justiça Tributária. Brasília: IPEA, 15 de maio de 2008, p.3.
} 
Em resumo, quanto maior a renda por décimos de renda, menor a tributação total e menor ainda a tributação indireta. Quanto menor a renda, maior a carga tributária total e maior a tributação indireta.

Por isso, devemos sair da antiga definição de contribuinte e passar a definição de cliente. Já há decisões da justiça ${ }^{7}$, que ao analisar a relação contribuinte/Estado-Fisco aplica o Código de Defesa do Consumidor, como numa relação de consumo, em cobrança de ICMS. Ora, o Estado não é um fornecedor de políticas públicas? É uma verdadeira transformação na postura do fisco em relação à cidadania.

Essa cidadania, aqui entendida conjuntamente com Dallari ${ }^{8}$, não é somente votar e pagar tributos. É participar da política e cobrar do Estado a diminuição dos contrastes sociais com os recursos arrecadados.

De outro lado, para o Centro de Informação Européia Jacques Delors (CIEJD), a palavra "Cidadania" tem origem etimológica no latim civitas, significando "cidade". Designa um estatuto de pertença de um indivíduo a uma comunidade politicamente articulada e que lhe atribui um conjunto de direitos e obrigações.

Ampliando o conceito, a cidadania fiscal pode ser percebida como a capacidade de entendimento da importância social dos tributos e a necessidade do controle, por parte da sociedade, dos gastos públicos. Por definição, imposto é algo que somos obrigados a aceitar. Mas como cidadãos temos o dever de cobrar a correta utilização dos recursos. Kant já afirmava que o Estado de Direito é a união dos homens sob o império da lei do Direito. Nesse contexto, o Estado Fiscal formado pela Constituição Tributária é uma das facetas da Constituição da União.

Só o Estado que cultiva a igualdade e a legalidade e que necessita de recursos mais abundantes que os da polis e das comunidades medievais é que se pode classificar como Estado Fiscal ${ }^{9}$. A fiscalidade é fenômeno que historicamente coincide com a formação dos Estados Nacionais. Para se manter, o Estado retira do povo sua alíquota de participação. Tal alíquota se exagerada pode causar a crise financeira do Estado que teria, segundo James O'Connor apud Torres (1986, p. 67), inúmeras causas, dentre as quais: o crescimento exagerado do setor público da

\footnotetext{
${ }^{7}$ Comarca de ljuí - 2 ${ }^{\text {a }}$ Vara Cível, Processo 62.935 - 2.000 (Embargos à Execução) Requerente: SABO MAGAZINE LTDA. Requerido: Estado do Rio Grande do Sul.

${ }^{8}$ Que entende que a cidadania expressa um conjunto de preceitos que dá ao cidadão comum o direito de participar ativamente da vida e do governo de seu povo.

${ }^{9}$ Cf. TORRES, p. 63.
} 
economia; a revolta fiscal por parte dos trabalhadores, que resistem ao aumento do volume de impostos; a proteção fiscal ao capital monopolista; o antagonismo ente os trabalhadores do setor público e do privado e as contradições entre as necessidades da União e dos Estados.

Jorge Maranhão ${ }^{10}$ afirma que não custa lembrar que toda a história da cidadania no mundo é no fundo uma história de cidadania fiscal, de cidadãos que se compreenderam como pagadores de impostos. Desde a revolta dos barões do século XIII, a Revolução Gloriosa inglesa no século XVII, a revolução americana no século XVIII e mesmo as várias insurreições havidas no Brasil durante os séculos XVIII e XIX. Todos esses movimentos, sem exceção, frutos da injustiça na repartição da arrecadação do bolo tributário. Mas, longe de se pensar em qualquer tipo de separatismo entre estados ricos e pobres, a verdade é que a atual carga tributária, somada com a recorrente impunidade de políticos e gestores públicos, tem transformado o equilíbrio entre estados numa peça de ficção, fazendo com que aqueles que pagam mais acabem pagando o pato dos demais que sequer têm condições produtivas para serem independentes de fato. E que, por isso mesmo, ficam condenados à condição de meros feudos eleitoreiros ao sabor dos senhores caciques e demagogos do momento.

Ainda, Segundo reportagem da Revista Super Interessante ${ }^{11}$, A enorme relevância dos impostos para a civilização humana fica evidente quando se percebe há quanto tempo eles existem. Tabletes de barro datados de 4000 a.C. encontrados na Mesopotâmia são os documentos escritos mais antigos conhecidos. Por isso, a região é conhecida como o berço da civilização. E o mais antigo desses documentos faz referência aos impostos. Além de entregar parte dos alimentos que produziam ao governo, os sumérios, um dos povos que viviam por ali, eram obrigados a passar até cinco meses por ano trabalhando para o rei. Os mais sortudos seriam empregados na colheita ou para retirar lama dos canais da cidade. Os menos afortunados entravam para o exército, onde poderiam morrer (o serviço militar obrigatório era uma forma de imposto). Os mais ricos mandavam escravos para trabalhar em seu lugar. Depois, com a invenção da moeda, passaram a pagar em dinheiro.

De outro lado, em 167 a.C., Roma se tornou tão rica à custa dos povos conquistados que suspendeu a cobrança de impostos sobre os cidadãos romanos.

\footnotetext{
${ }^{10} \mathrm{http}: / /$ www.avozdocidadao.com.br/detailEditorial.asp?ID=1297\&SM=1\%2329\&pagina=

${ }^{11} \mathrm{http}: / /$ super.abril.com.br/superarquivo/2003/conteudo_288225.shtml
} 
Mais que isso, distribuía pão e outros produtos gratuitamente na cidade como forma de partilhar a riqueza. Como o império era muito grande, terceirizaram a coleta de impostos. Os publicani, ou fiscais, adiantavam dinheiro ao governo pelo direito de recolher os impostos e, depois, tratavam de recuperar o investimento acrescido de juros, custos de coleta e, naturalmente, algum lucro. Ainda assim, calcula-se que menos de $10 \%$ do PIB do império era cobrado em impostos. Isso porque os gastos do governo eram limitados. Mais ou menos $50 \%$ do orçamento era dedicado à manutenção do exército, inclusive o primeiro sistema de previdência da história, que garantia aos legionários 13 anos de salário depois que cumprissem 25 anos de serviço. O resto era destinado a cobrir as despesas do governante, à construção de estradas, portos e mercados e à manutenção do sistema legal. Isso mostra uma das características mais consistentes dos impostos ao longo da história. $\mathbf{O}$ valor recolhido é função do quanto o governo quer gastar e não da percepção sobre quanto é justo tirar de cada cidadão. Afinal, os romanos, que se consideravam donos dos povos conquistados, cobravam-lhes menos do que muitos governos cobram, hoje, daqueles a quem deveriam servir.

Atualmente, para atingir seus objetivos, o Estado retira da sociedade recursos financeiros que, via de regra, são empregados na implantação de políticas públicas $^{12}$.

A escolha da política pública adequada e a quantidade de recursos necessários passam ao largo da discussão da sociedade. Por isso é necessário despertar na sociedade a importância do controle das finanças do Estado, afinal é o recurso de todos sendo aplicado no bem comum.

Nelson Barbosa, Secretário-Executivo do Ministério da Fazenda, em seminário na comissão especial da Câmara dos Deputados que discutiu a reforma tributária, no dia 10 de maio de 2011, afirmou que "a carga tributária poderá subir, cair ou continuar a mesma depois da reforma. Para nós, a carga tributária ideal deve ter o tamanho necessário para o Estado prover a sociedade dos serviços de que necessita".

Como assim? Parece que o ente público está desconectado da sociedade a que pertence. Segundo o Instituto Brasileiro de Planejamento Tributário (IBPT), em

\footnotetext{
${ }^{12}$ Conjunto de ações desencadeadas pelo Estado, nas escalas federal, estadual e municipal, com vistas ao bem coletivo.
} 
2009 a carga tributária brasileira atingiu 34,50\% do Produto Interno Bruto $^{13}$ (PIB). Mais de um terço do que produzimos vai para o Estado em forma de tributos. Fica evidente que temos carga tributária de país desenvolvido e prestação de serviços à sociedade de país subdesenvolvido.

Esta alta tributação, concentrada no consumo, se traduz em grande arrecadação e ainda consegue de maneira transversa diminuir o crescimento sustentável da economia. Mas, ao tributar excessivamente o consumo, o governo deixa de ganhar receita em grande escala. Assim dificulta o acesso da camada mais baixa da população aos bens básicos do consumo. A solução é desonerar o consumo e aumentar a tributação sobre o patrimônio. O problema é que as receitas estão distribuídas em três níveis e o consumo corresponde ao financiamento dos Estados que já não podem perder sua maior fonte de receita.

Para melhor verificar a assertiva acima, é necessário estudar a arrecadação dos tributos. Em termos comparativos e conforme dados da Secretaria de Fazenda do Governo do Distrito Federal (GDF), a arrecadação total do GDF vem numa crescente. No ano de 2007, o total de receitas arrecadadas foi de $R \$$ 8.632.000.000,00, e em 2010, de $\mathrm{R} \$ 12.544 .000 .000,00$. Um crescimento de 45,31\% em três anos. As receitas tributárias que em 2007 foram de $R \$$ 6.074.000.000,00, em 2010, foram de $\mathrm{R} \$$ 8.353.000.000,00. Um aumento de 37,52\%. No mesmo período o IPCA ${ }^{14}$ acumulado foi de $20,56 \%$. Se compararmos com o aumento do PIB no período, de $17,10 \%$, há uma grande diferença que só pode ser justificada pelo aumento da carga tributária.

Neste contexto, no ano de 2010, o ICMS correspondeu a 54\%, o IRPF a $18 \%$, o ISS a $10 \%$, o IPVA a $6 \%$, o IPTU a 5\%, o ITBI a $3 \%$, o Imposto SIMPLES a $2 \%$, as taxas a $2 \%$ e o ITCD a $0 \%$ do total de receitas tributárias.

Segundo Álvaro Taiar, coordenador de pesquisa feita pela Price Waterhouse Coopers ${ }^{15}$, os empresários repassam para os preços tudo o que pagam em impostos, e a conseqüência disso é a queda do consumo, que desestimula novos investimentos e trava a economia.

\footnotetext{
${ }^{13}$ Representa a soma (em valores monetários) de todos os bens e serviços finais produzidos numa determinada região (quer seja, países, estados, cidades), durante um período determinado (mês, trimestre, ano, etc). O PIB é um dos indicadores mais utilizados na macroeconomia com o objetivo de mensurar a atividade econômica de uma região.

${ }^{14}$ O IPCA (Índice de Preços ao Consumidor Amplo), medido mensalmente pelo IBGE (Instituto Brasileiro de Geografia e Estatística), foi criado com o objetivo de oferecer a variação dos preços no comércio para o público final. O IPCA é considerado o índice oficial de inflação do país.

${ }^{15}$ Jornal O Estado de São Paulo, em 29/04/2002.
} 


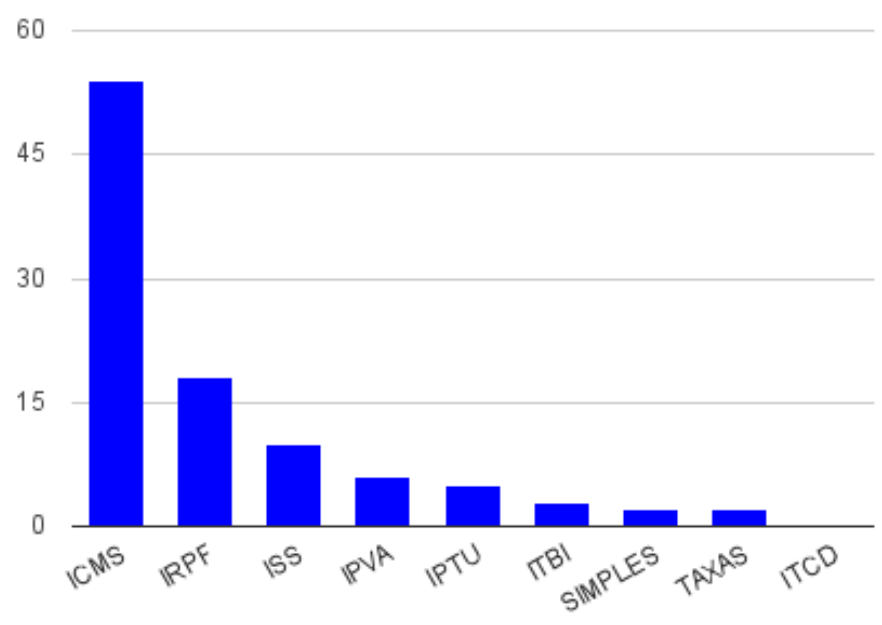

Figura 2 - Arrecadação Tributária do GDF, 2010

O ideal é o país adequar sua despesa à sua receita e não aumentar a receita para fazer face ao aumento da despesa.

Levantamento de uma associação internacional de consultorias indicou que o Brasil tem uma carga tributária considerada leve para as classes mais altas.

Segundo reportagem do UOL Economia, pesquisa da rede UHY, com sede em Londres, descobriu que um profissional que recebe até US\$25 mil por ano - cerca de R\$3.300 por mês - no Brasil, leva, após o pagamento de imposto de renda e previdência, $84 \%$ do seu salário para casa. Já os profissionais que recebem US\$200 mil por ano - cerca de $R \$ 26.600$ por mês - recebem no final cerca de $74 \%$ de seu pagamento. Entre 20 países pesquisados pela UHY, essa diferença de cerca de 10 pontos percentuais é uma das menores. Na Holanda, onde um profissional na faixa mais baixa recebe um valor líquido semelhante ao do Brasil após os impostos e encargos $(84,3 \%)$, os mais ricos levam para casa menos de $55 \%$ do salário. A lógica também se aplica a todos os países do G7, o grupo de países mais industrializados do mundo (EUA, Canadá, Japão, Grã-Bretanha, Alemanha, França e Itália). Nos EUA, enquanto os mais ricos levam para casa $70 \%$ do salário, os profissionais na 
faixa dos US\$25 mil anuais deixam apenas um décimo da renda para o governo e a previdência $^{16}$.

Ainda, segundo reportagem do Jornal O Globo, o custo do financiamento e a carga tributária elevada foram os principais fatores de limitação dos investimentos em capital fixo na indústria de transformação previstos para este ano. A Sondagem de Investimento, divulgada pelo Instituto Brasileiro de Economia da Fundação Getúlio Vargas (Ibre-FGV), apontou que, das empresas com dificuldade para realizar investimentos em capital fixo neste ano, 42\% apontaram a carga tributária elevada como um entrave considerável, percentual que atingiu 33\% para o custo do financiamento. Das 812 companhias pesquisadas, apenas 33\% afirmaram encontrar problemas para realizar investimento em 2011, mesmo percentual do ano passado, mas bem abaixo dos $87 \%$ de 2009 , ano em que os efeitos da crise internacional ecoavam na economia brasileira ${ }^{17}$.

Por isso é necessário pesquisar o impacto dos programas de incentivo fiscal na renda da população economicamente ativa e avaliar a possibilidade de ampliá-los para que se alcance o maior número de pessoas, produzindo com isso uma diminuição da carga tributária e o desenvolvimento da cidadania fiscal do contribuinte.

\footnotetext{
${ }^{16} \mathrm{http}: / /$ economia.uol.com.br/ultimas-noticias/bbc/2011/06/21/brasil-tem-carga-tributaria-leve-pararicos-diz-estudo.jhtm, acessado em 21/06/2011

${ }_{17} \mathrm{http}: / /$ oglobo.globo.com/pais/mat/2011/06/20/carga-tributaria-custo-do-credito-sao-entraves-aoinvestimento-diz-924723954.asp\#ixzz1QbcOWloe, acessado em 20/06/2011
} 


\section{OS TRIBUTOS E OS PROGRAMAS DE DIMINUIÇÃO DA CARGA TRIBUTÁRIA}

"no taxation without representation" ${ }^{18}$

Despesas Públicas! Como financiá-las? As necessidades são infinitas, mas finitos são os recursos. Desde a Carta Magna imposta a João Sem Terra, em 1215, no Reino da Inglaterra, a sociedade tenta impor limites ao voraz apetite arrecadatório do Estado. O rei passou a ser vinculada a lei por ele editada.

As grandes revoluções da história tiveram como uma das causas, a carga tributária imposta. Na Revolução Francesa, a igualdade se traduzia na capacidade tributária a todos devida. Não mais poderia se falar em classes excluídas na cobrança de tributos.

No Brasil, a Inconfidência Mineira teve como causa a derrama, o excessivo imposto cobrado da Colônia em favor de Portugal. Um dos principais motivos que levaram o Rio Grande do Sul à guerra por sua independência eram os elevados impostos sobre o gado em pé e a arroba de charque, os principais produtos do estado. Por sua vez, o Império do Brasil criou, em 1845, o primeiro imposto de renda brasileiro para financiar a guerra farroupilha. $\mathrm{Na}$ atualidade, vivese dias de pesada carga tributária. Trabalha-se quase cinco meses em doze para custear o Estado Brasileiro. Talvez, por perceber isso, e sem a possibilidade de uma verdadeira reforma tributária à vista, como a ocorrida em $1966 \mathrm{com}$ a lei que instituiu o Código Tributário Nacional, os governos estaduais e municipais vem adotando programas com a finalidade de reduzir os tributos cobrados.

Para Martins apud Barbosa, a carga tributária é desmedida pelos seguintes motivos:
a. Objetivos e necessidades mal colocados;
b. Gastos supérfluos;
c. Contribuintes apenados, porque privilégios e incentivos são mal distribuídos;
d. Sonegação e tratamento prático diferencial;
e. Fiscalização, com baixa moralidade exatora; e

\footnotetext{
${ }^{18}$ Só paga imposto quem está representado, ou seja, quem consentiu indiretamente, através do voto, na tributação.
} 
f. Sonegação e aumento de receita, que se traduz pelo princípio de que a tributação seria mais elevada para compensar a receita não arrecadada dos sonegadores.

Com a finalidade de estudar o tema, a seguir serão apresentados os conceitos de tributos, os principais tributos envolvidos nos programas e alguns programas instituídos.

Por tributo, entende-se toda prestação pecuniária compulsória em moeda ou cujo valor nela se possa exprimir, que não constitua sanção de ato ilícito, instituída em lei e cobrada mediante atividade administrativa plenamente vinculada, conforme art. $3^{\circ}$ do Código Tributário Nacional (CTN).

Nos termos do art. 145 da Constituição Federal e do art. 5ํำ do CTN, tributos são classificados em:

a) Impostos.

b) Taxas, cobradas em razão do exercício do poder de polícia ou pela utilização, efetiva ou potencial, de serviços públicos específicos e divisíveis, prestados ao contribuinte ou postos à sua disposição.

c) Contribuição de melhoria, decorrente de obras públicas.

2.1 Principais tributos, incidentes sobre o consumo, envolvidos nos programas de incentivo fiscal

2.1.1 Imposto sobre circulação de mercadorias e sobre prestação de serviços de transporte interestadual, intermunicipal e de comunicação (ICMS)

O ICMS é de competência dos Estados e do Distrito Federal. Sua regulamentação constitucional é prevista na Lei Complementar 87/1996 (a chamada "Lei Kandir"), alterada posteriormente pelas Leis Complementares 92/97, 99/99 e 102/2000.

\subsubsection{Incidência do ICMS}

O imposto incide sobre:

1 - operações relativas à circulação de mercadorias, inclusive o fornecimento de alimentação e bebidas em bares, restaurantes e estabelecimentos similares;

II - prestações de serviços de transporte interestadual e intermunicipal, por qualquer via, de pessoas, bens, mercadorias ou valores; 
III - prestações onerosas de serviços de comunicação, por qualquer meio, inclusive a geração, a emissão, a recepção, a transmissão, a retransmissão, a repetição e a ampliação de comunicação de qualquer natureza;

IV - fornecimento de mercadorias com prestação de serviços não compreendidos na competência tributária dos Municípios;

$\mathrm{V}$ - fornecimento de mercadorias com prestação de serviços sujeitos ao imposto sobre serviços, de competência dos Municípios, quando a lei complementar aplicável expressamente o sujeitar à incidência do imposto estadual.

$\mathrm{VI}$ - a entrada de mercadoria importada do exterior, por pessoa física ou jurídica, ainda quando se tratar de bem destinado a consumo ou ativo permanente do estabelecimento;

VII - o serviço prestado no exterior ou cuja prestação se tenha iniciado no exterior;

VIII - a entrada, no território do Estado destinatário, de petróleo, inclusive lubrificantes e combustíveis líquidos e gasosos dele derivados, e de energia elétrica, quando não destinados à comercialização ou à industrialização, decorrentes de operações interestaduais, cabendo o imposto ao Estado onde estiver localizado o adquirente.

O imposto não incide sobre:

I - operações com livros, jornais, periódicos e o papel destinado a sua impressão;

II - operações e prestações que destinem ao exterior mercadorias, inclusive produtos primários e produtos industrializados semi-elaborados, ou serviços;

II - operações interestaduais relativas a energia elétrica e petróleo, inclusive lubrificantes e combustíveis líquidos e gasosos dele derivados, quando destinados à industrialização ou à comercialização;

IV - operações com ouro, quando definido em lei como ativo financeiro ou instrumento cambial;

V - operações relativas a mercadorias que tenham sido ou que se destinem a ser utilizadas na prestação, pelo próprio autor da saída, de serviço de qualquer natureza definido em lei complementar como sujeito ao imposto sobre serviços, de competência dos Municípios, ressalvadas as hipóteses previstas na mesma lei complementar; 
$\mathrm{VI}$ - operações de qualquer natureza de que decorra a transferência de propriedade de estabelecimento industrial, comercial ou de outra espécie;

VII - operações decorrentes de alienação fiduciária em garantia, inclusive a operação efetuada pelo credor em decorrência do inadimplemento do devedor;

VIII - operações de arrendamento mercantil, não compreendida a venda do bem arrendado ao arrendatário;

IX - operações de qualquer natureza de que decorra a transferência de bens móveis salvados de sinistro para companhias seguradoras.

Equipara-se às operações de que trata o item II a saída de mercadoria realizada com o fim específico de exportação para o exterior, destinada a:

a) empresa comercial exportadora, inclusive tradings ou outro estabelecimento da mesma empresa;

b) armazém alfandegado ou entreposto aduaneiro.

\subsubsection{Contribuinte do ICMS}

Contribuinte é qualquer pessoa, física ou jurídica, que realize, com habitualidade ou em volume que caracterize intuito comercial, operações de circulação de mercadoria ou prestações de serviços de transporte interestadual e intermunicipal e de comunicação, ainda que as operações e as prestações se iniciem no exterior.

É também contribuinte a pessoa física ou jurídica que, mesmo sem habitualidade:

I - importe mercadorias do exterior, ainda que as destine a consumo ou ao ativo permanente do estabelecimento;

II - seja destinatária de serviço prestado no exterior ou cuja prestação se tenha iniciado no exterior,

III - adquira em licitação mercadorias apreendidas ou abandonadas;

IV - adquira lubrificantes e combustíveis líquidos e gasosos derivados de petróleo e energia elétrica oriundos de outro Estado, quando não destinados à comercialização ou à industrialização.

\subsubsection{Local da operação ou da prestação do ICMS \\ O local da operação ou da prestação, para os efeitos da cobrança do imposto e definição do estabelecimento responsável, é:}


I - tratando-se de mercadoria ou bem:

a) o do estabelecimento onde se encontre, no momento da ocorrência do fato gerador;

b) onde se encontre, quando em situação irregular pela falta de documentação fiscal ou quando acompanhado de documentação inidônea, como dispuser a legislação tributária;

c) o do estabelecimento que transfira a propriedade, ou o título que a represente, de mercadoria por ele adquirida no País e que por ele não tenha transitado;

d) importado do exterior, a do estabelecimento onde ocorrer à entrada física;

e) importado do exterior, o do domicílio do adquirente, quando não estabelecido;

f) aquele onde seja realizada a licitação, no caso de arrematação de mercadoria importada do exterior e apreendida;

g) o do Estado onde estiver localizado o adquirente, inclusive consumidor final, nas operações interestaduais com energia elétrica e petróleo, lubrificantes e combustíveis dele derivados, quando não destinados à industrialização ou à comercialização;

h) o do Estado de onde o ouro tenha sido extraído, quando não considerado como ativo financeiro ou instrumento cambial;

i) o de desembarque do produto, na hipótese de captura de peixes, crustáceos e moluscos;

II - tratando-se de prestação de serviço de transporte:

a) onde tenha início à prestação;

b) onde se encontre o transportador, quando em situação irregular pela falta de documentação fiscal ou quando acompanhada de documentação inidônea, como dispuser a legislação tributária;

c) o do estabelecimento destinatário do serviço, na hipótese da utilização, por contribuinte, de serviço cuja prestação se tenha iniciado em outro Estado e não esteja vinculada a operação ou prestação subseqüente;

III - tratando-se de prestação onerosa de serviço de comunicação: 
a) o da prestação do serviço de radiodifusão sonora e de som e imagem, assim entendido o da geração, emissão, transmissão e retransmissão, repetição, ampliação e recepção;

b) o do estabelecimento da concessionária ou da permissionária que forneça ficha, cartão, ou assemelhados com que o serviço é pago;

c) o do estabelecimento destinatário do serviço, na hipótese da utilização, por contribuinte, de serviço cuja prestação se tenha iniciado em outro Estado e não esteja vinculada a operação ou prestação subseqüente;

d) o do estabelecimento ou domicílio do tomador do serviço, quando prestado por meio de satélite;

d) onde seja cobrado o serviço, nos demais casos.

IV - tratando-se de serviços prestados ou iniciados no exterior, o do estabelecimento ou do domicílio do destinatário.

\subsubsection{Ocorrência do fato gerador do ICMS}

Considera-se ocorrido o fato gerador do imposto no momento:

I - da saída de mercadoria de estabelecimento de contribuinte, ainda que para outro estabelecimento do mesmo titular;

II - do fornecimento de alimentação, bebidas e outras mercadorias por qualquer estabelecimento;

III - da transmissão a terceiro de mercadoria depositada em armazém geral ou em depósito fechado, no Estado do transmitente;

IV - da transmissão de propriedade de mercadoria, ou de título que a represente, quando a mercadoria não tiver transitado pelo estabelecimento transmitente;

V - do inicio da prestação de serviços de transporte interestadual e intermunicipal, de qualquer natureza;

$\mathrm{VI}$ - do ato final do transporte iniciado no exterior;

VII - das prestações onerosas de serviços de comunicação, feita por qualquer meio, inclusive a geração, a emissão, a recepção, a transmissão, a retransmissão, a repetição e a ampliação de comunicação de qualquer natureza;

VIII - do fornecimento de mercadoria com prestação de serviços:

a) não compreendidos na competência tributária dos Municípios; 
b) compreendidos na competência tributária dos Municípios e com indicação expressa de incidência do imposto da competência estadual, como definido na lei complementar aplicável,

IX - do desembaraço aduaneiro das mercadorias importadas do exterior;

$X$ - do recebimento, pelo destinatário, de serviço prestado no exterior;

XI - da aquisição em licitação pública de mercadorias importadas do exterior apreendidas ou abandonadas;

XII - da entrada no território do Estado de lubrificantes e combustíveis líquidos e gasosos derivados de petróleo e energia elétrica oriundos de outro Estado, quando não destinados à comercialização ou à industrialização;

XIII - da utilização, por contribuinte, de serviço cuja prestação se tenha iniciado em outro Estado e não esteja vinculada a operação ou prestação subseqüente.

\subsubsection{Alíquota e base de cálculo do ICMS}

As alíquotas internas são livremente estipuladas pelos Estados e o Distrito Federal, normalmente $17 \%$ a $18 \%$ para operações e serviços em geral e $25 \%$ para comunicações. Operações interestaduais destinadas a contribuintes localizados nos Estados de Minas Gerais, Rio de Janeiro, São Paulo, Paraná, Santa Catarina e Rio Grande do Sul são tributadas em 12\%. Para os Demais Estados a alíquota é de 7\%.

A base de cálculo deve representar a quantificação compreendida na operação mercantil e na prestação de serviço de transporte e de comunicação.

No Distrito Federal, as alíquotas do imposto, seletivas em função da essencialidade das mercadorias e serviços, são:

I - nas operações e prestações interestaduais destinadas a contribuinte do imposto:

a) $4 \%$ (a quatro por cento), na prestação de transporte aéreo interestadual de carga e mala postal;

b) $12 \%$ (doze por cento), nos demais casos.

II - nas operações e prestações internas:

a) de $25 \%$ (vinte e cinco por cento), para:

1) armas e munições;

2) embarcações de esporte e recreação; 
3) energia elétrica, para classe residencial e Poder Público, acima de 500 KWh mensais;

4) bebidas alcoólicas;

5) fumo, seus derivados, cachimbos, cigarreiras, piteiras e isqueiros;

6) fogos de artifício;

7) peleterias;

8) petróleo e combustíveis líquidos ou gasosos, exceto óleo diesel, lubrificantes e gás liquefeito de petróleo-glp;

9) artigos de antiquário;

10) aviões de procedência estrangeira de uso não comercial, asas-delta e ultraleves, suas peças e acessórios;

11) serviços de comunicação;

b) de $21 \%$ (vinte e um por cento), para energia elétrica, classe residencial, de 301 a 500 KWh mensais, e classes industrial e comercial, acima de $1.000 \mathrm{KWh}$ mensais;

c) de $17 \%$ (dezessete por cento), para lubrificantes e demais mercadorias e serviços;

d) de $12 \%$ (doze por cento), para:

1) fornecimento ou saída de refeição, bebidas não-industrializadas e sobremesas, por restaurantes, bares e estabelecimentos similares ou por empresas preparadoras de refeições coletivas;

2) óleo diesel e gás liquefeito de petróleo-glp;

3) energia elétrica até $200 \mathrm{KWh}$ mensais;

4) máquinas industriais, diretamente utilizadas no processo produtivo;

5) móveis e mobiliário médico-cirúrgico;

6) máquinas registradoras;

7) vestuário e seus acessórios;

8) papel, formulário contínuo e impressos, nas operações realizadas pelos estabelecimentos industriais e atacadistas;

9) produtos da indústria de informática e automação e suporte físico e programa de computadores, quando não seja elaborado sob encomenda, exceto jogos;

10) pneu recauchutado;

11) areia. 
12) obras de marcenaria ou de carpintaria para construções, incluídos os painéis celulares, os painéis para soalhos e as franquias para telhados.

III - nas importações realizadas por contribuintes do ICMS, 12\% (doze por cento).

2.1.2 Imposto sobre serviços de qualquer natureza (ISS)

O ISS, de competência dos Municípios e do Distrito Federal, tem como fato gerador a prestação de serviços constantes da lista anexa à Lei Complementar 116/2003, ainda que esses não se constituam como atividade preponderante do prestador. O ISS, até 31.07.2003, foi regido pelo DL 406/1968 e alterações posteriores. A partir de 01.08.2003, o ISS é regido pela Lei Complementar (LC) $116 / 2003$.

\subsubsection{Contribuinte do ISS}

Contribuinte é o prestador do serviço.

\subsubsection{Local dos serviços do ISS}

O serviço considera-se prestado e o imposto devido no local do estabelecimento prestador ou, na falta do estabelecimento, no local do domicílio do prestador, exceto nas hipóteses previstas nos itens I a XXII do art. $3^{\circ}$ da Lei Complementar 116/2003.

Anteriormente a edição da LC 116/2003, o STJ manifestou entendimento jurisprudencial que o local de recolhimento do ISS é onde são prestados os serviços ${ }^{19}$.

\subsubsection{Alíquota do ISS}

19 Acórdão STJ 252.114-PR. EMENTA TRIBUTÁRIO - ISS - SERVIÇOS DE COMPOSIÇÃO GRÁFICA - MUNICÍPIO COMPETENTE PARA EXIGIR - LOCAL DA REALIZAÇÃO DO FATO GERADOR - INTERPRETAÇÃO DO ART. 12 DO DECRETO-LEI 406/68 - PRECEDENTES Consoante iterativa jurisprudência desta eg. Corte, o Município competente para a cobrança do ISS é aquele em cujo território se realizou o fato gerador, em atendimento ao princípio constitucional implícito que atribui àquele Município, o poder de tributar os serviços ocorridos em seu território. Executados os serviços de composição gráfica em estabelecimentos localizados em outros municípios, não tem a Municipalidade de Curitiba competência para exigir ISS referente a esses fatos geradores. Recurso Especial não conhecido. 
A Emenda Constitucional 37/2002, em seu art. 3º, incluiu o art. 88 ao Ato das Disposições Constitucionais Transitórias, fixando a alíquota mínima do ISS em 2\% (dois por cento), a partir da data da publicação da Emenda (13.06.2002).

A alíquota máxima de incidência do ISS foi fixada em $5 \%$ pelo art. 8, II, da Lei Complementar 116/2003. O ISS não incide sobre as exportações de serviços para o exterior do País, mas são tributáveis os serviços desenvolvidos no Brasil, cujo resultado aqui se verifique, ainda que o pagamento seja feito por residente no exterior.

2.2 Principais tributos, incidentes sobre o patrimônio, envolvidos nos programas de incentivo fiscal

\subsubsection{Imposto sobre a propriedade de veículos automotores (IPVA)}

É um imposto estadual, ou seja, somente os Estados e o Distrito Federal têm competência para instituí-lo conforme art. 155, III da Constituição Federal. Do total arrecadado por cada veículo, $50 \%$ é destinado ao governo estadual, enquanto que os outros $50 \%$ são destinados ao município onde o veículo foi emplacado.

\subsubsection{Incidência do IPVA}

O IPVA tem como fato gerador a propriedade de veículo automotor de qualquer espécie, sujeito ao registro, matrícula ou licenciamento no Estado.

\subsubsection{Contribuinte do IPVA \\ É o proprietário do veículo;}

\subsubsection{Ocorrência do fato gerador do IPVA}

Considera-se ocorrido o fato gerador do imposto em $1^{\circ}$ de janeiro de cada exercício.

Em se tratando de veículo novo, considera-se ocorrido o fato gerador na data de sua aquisição por pessoa física ou jurídica ou quando da incorporação ao ativo permanente por empresa fabricante ou revendedora.

Em se tratando de veículo usado não registrado e não licenciado no Estado, considera-se ocorrido o fato gerador na data da aquisição, quando não houver comprovação do pagamento do IPVA em outra Unidade da Federação. 
O IPVA será devido no local do domicílio do proprietário do veículo.

\subsubsection{Alíquota e base de cálculo do IPVA}

A alíquota será estabelecida na lei ordinária, que normalmente fixa percentuais distintos, tendo em vista a diversidade dos veículos.

A base de cálculo é o valor venal do veículo.

No Distrito Federal, as alíquotas do imposto são a seguir discriminadas:

I - 1\% (um por cento), para os veículos automotores classificados como caminhões, cavalos-mecânicos, ônibus e microônibus detentores de permissão para transporte público de passageiros, máquinas de terraplenagem, equipamentos automotores especiais, embarcações e aeronaves;

II - 1\% (um por cento) para veículos de carga com lotação acima de 2.000 $\mathrm{kg}$, caminhões-tratores, microônibus, ônibus e tratores de esteira, de rodas ou mistos;

III - 2\% (dois por cento), para motos, ciclomotores, triciclos e quadriciclos;

IV - $2 \%$ (dois por cento) para ciclomotores, motocicletas, motonetas, quadriciclos e triciclos;

V - 3\% (três por cento) para automóveis, inclusive de esporte ou corrida, bem como para camionetes de uso misto e veículos utilitários de fabricação nacional ou estrangeira.

$\mathrm{VI}$ - 4\% (quatro por cento), para os veículos relacionados no inciso anterior, de fabricação estrangeira.

2.2.2 Imposto sobre a propriedade predial e territorial urbana (IPTU)

O Imposto sobre a propriedade predial e territorial urbana (IPTU) instituído pela Constituição Federal cuja incidência se dá sobre a propriedade urbana. Ou seja, o IPTU tem como fato gerador a propriedade, o domínio útil ou a posse de propriedade imóvel localizada em zona urbana ou extensão urbana. A função do IPTU é tipicamente fiscal, embora também possua função social. Sua finalidade principal é a obtenção de recursos financeiros para os municípios, embora ele também possa ser utilizado como instrumento urbanístico de controle do preço da terra.

\subsubsection{Incidência do IPTU}


Incide em $1^{\underline{0}}$ de janeiro de cada exercício sobre todos os imóveis localizados na Zona Urbana do Município. Portanto, a propriedade predial e territorial urbana, localizada dentro da Zona Urbana do Município é o fato gerador do IPTU.

\subsubsection{Contribuinte do IPTU}

Preceitua o art. 34, do CTN que: "Art. 34. Contribuinte do imposto é o proprietário do imóvel, o titular do seu domínio útil, ou o seu possuidor a qualquer título".

\subsubsection{Ocorrência do fato gerador do IPTU}

Conforme o art. 32, do CTN, o fato gerador do IPTU é a propriedade, o domínio útil ou a posse de bem imóvel por natureza ou por acessão física, como definido na lei civil, localizado na zona urbana do Município

\subsubsection{Alíquota e base de cálculo do IPTU}

As alíquotas do imposto são estabelecidas em lei municipal ou distrital. $\mathrm{O}$ imposto poderá ser progressivo em razão do valor do imóvel e ter alíquotas diferentes de acordo com a localização e o uso do imóvel. A base de cálculo é o valor venal do imóvel apurado pela prefeitura, sendo indiferente à destinação que lhe é dada.

No Distrito Federal, as alíquotas do imposto são a seguir discriminadas:

I - 3\% (três por cento) do valor venal:

a) do terreno não edificado;

b) dos terrenos com edificações em construção ou demolição, condenadas ou em ruínas, quando nelas se constatar a existência de dependências suscetíveis de utilização;

II - $1 \%$ (um por cento) do valor venal:

a) do imóvel não residencial, edificado;

b) do imóvel residencial portador de alvará de construção, pelo prazo improrrogável de trinta e seis meses, contado da data de expedição do documento pelo órgão competente, desde que o proprietário do imóvel não seja titular de outro, da mesma natureza, no Distrito Federal;

III - 0,30\% (trinta centésimos por cento) do valor venal do imóvel edificado exclusivamente para fins residenciais. 
III - 0,30\%(trinta centésimos por cento) do valor venal:

a) do imóvel edificado exclusivamente para fins residenciais;

b) das unidades superiores dos imóveis com utilização residencial, especialmente nos Setores Comerciais Locais Sul e Norte, Setor de Edifícios de Utilidade Pública, Setor de Habitação Coletiva Sudoeste - SHCW.

\subsection{Programas de incentivo fiscal}

2.3.1 Programa de incentivo fiscal do Governo do Estado de São Paulo - Nota Paulista

O Programa Nota Paulista do Governo do Estado de São Paulo é um incentivo para que os cidadãos que adquirem mercadorias exijam do estabelecimento comercial o documento fiscal. Os consumidores que informarem o seu CPF ou CNPJ no momento da compra poderão escolher como receber os créditos e ainda concorrerão a prêmios em dinheiro.

Implementado pela Lei № 12.685/2007 e pelos Decretos № 52.096/2007 e $54.179 / 2009$, tem por objetivo estimular os consumidores a exigirem a entrega do documento fiscal na hora da compra de mercadorias, bens ou serviços de contribuinte do ICMS. Para estimular o contribuinte a pedir a nota fiscal, distribui créditos às pessoas físicas, às empresas optantes pelo regime do Simples Nacional (com faturamento de até $R \$ 240.000,00$ ao ano), entidades da assistência social e da área da saúde e condomínios edilícios.

Para isso, o consumidor deve solicitar o documento fiscal no ato da compra e informar o seu CPF ou CNPJ para ter direito aos créditos e concorrer a prêmios.

Os estabelecimentos comerciais enviarão periodicamente essas informações para a Secretaria da Fazenda, que calculará o crédito do consumidor.

\subsubsection{Características do programa Nota Paulista}

A ampliação da base de contribuintes pela demanda por emissão de Notas e Cupons Fiscais, cruzamento eletrônico de informações e aprimoramento dos controles fiscais.

A redução de custos de aquisição de papel, redução de custos de impressão e armazenagem de documentos fiscais, simplificação das obrigações 
acessórias e incentivo ao uso de relacionamentos eletrônicos com clientes. 0 programa caminha no sentido da informatização de documentos em papel transformando-os em eletrônicos, pois exige que todas as notas emitidas sejam registradas pelos estabelecimentos no banco de dados da Secretaria da Fazenda.

\subsubsection{Forma de estímulo para o contribuinte do programa Nota Paulista}

Os consumidores que se identificam com o CPF ou CNPJ na nota ou cupom fiscal recebem até $30 \%$ do ICMS recolhido pelo estabelecimento comercial, implicando na redução na carga tributária.

Ainda, o consumidor que preferir não se identificar com o CPF poderá doar suas notas para entidades de assistência social ou da área da saúde para receberem o crédito em seu lugar.

Sorteios mensais de prêmios a cada $R \$ 100,00$ em compras no mês dá direito ao consumidor pessoa física, à entidade de assistência social e da área da saúde e ao condomínio edilício a um bilhete eletrônico para concorrer no sorteio.

\subsubsection{Funcionamento do sistema do programa Nota Paulista}

Em cada compra, o consumidor informa seu CPF/CNPJ e solicita sua Nota Fiscal/Cupom Fiscal ou Nota Fiscal on-line. O vendedor registra o CPF/CNPJ do comprador. Ele emite o Cupom Fiscal, a Nota Fiscal Tradicional ou gera, no site, a Nota on-line.

Após o recolhimento do ICMS pelo estabelecimento, a Secretaria da Fazenda creditará ao consumidor a parcela do imposto a que ele tem direito, proporcional ao valor da compra.

O crédito poderá, dentro de cinco anos, ser utilizado para reduzir o valor do débito do IPVA, transferido para conta corrente ou poupança.

2.3.2 Programa de incentivo do Governo do Município de São Paulo - Nota Paulistana

A Prefeitura do Município de São Paulo, desde 2005, instituiu, conforme Lei 14.097/05, regulamentada pelo Decreto 47.350/06, o programa NF-e (Nota Fiscal Eletrônica) o qual visa simplificar a vida dos prestadores de serviços e gerar créditos para seus clientes, e as empresas da cidade de São Paulo. O cliente (tomador de 
serviços) que pedir a emissão da NF-e poderá utilizar parte do ISS recolhido para abater até $50 \%$ do IPTU.

A emissão da NF-e busca reduzir a carga tributária individual e simplificar o cumprimento de obrigações acessórias pelas empresas.

\subsubsection{Características do programa Nota Paulistana}

a. Documento digital gerado e armazenado nos computadores da PMSP;

b. Garantia de autoria, integridade e irrefutabilidade, certificada por meio de senha;

c. Disponível para consulta on-line por 5 anos e em meio magnético por prazo indeterminado.

d. Redução dos custos de confecção de talonário de notas fiscais e/ou de sua impressão;

e. Redução de custos de aquisição de papel;

f. Redução de custos de armazenagem de documentos fiscais;

g. Incentivo a uso de relacionamentos eletrônicos com clientes.

h. Simplificação de obrigações acessórias como: eliminação da AIDF (Autorização de Impressão de Documentos Fiscais) e da DES (Declaração Eletrônica de Serviços);

i. Maiores recursos para o gerenciamento das Notas Fiscais emitidas e recebidas;

j. Eliminação dos erros de cálculo e do preenchimento de documentos de arrecadação, bem como no registro do seu pagamento.

k. Redução da carga tributária individual;

I. Redução de custos de armazenagem de documentos fiscais;

m. Incentivo a uso de relacionamentos eletrônicos com prestadores.

n. Redução da sonegação;

o. Aumento da arrecadação;

p. Maior efetividade nas ações de fiscalização;

q. Fim da prática de notas calçadas;

r. Suporte aos projetos de escrituração eletrônica contábil e fiscal da SRF.

s. Ampliação da base de contribuintes pela demanda por emissão de NFe; 
t. Redução da prática de simulação fiscal, já que somente os prestadores de serviço estabelecidos no Município poderão gerar crédito.

2.3.2.2 Forma de estímulo para o contribuinte do programa Nota Paulistana

Crédito de $30 \%$ do ISS incidente sobre o serviço contratado e que poderá ser utilizado para o abatimento de até $50 \%$ do IPTU

\subsubsection{Funcionamento do sistema do programa Nota Paulistana}

Quando contratar um serviço, o contribuinte deve solicitar a emissão da NF-e e o sistema efetuará automaticamente o cálculo do ISS devido pelo Prestador;

A alíquota do ISS varia de $2 \%$ a $5 \%$ sobre o valor do serviço, exceto para as empresas incluídas no SIMPLES (ME) cuja alíquota é de $1 \%$.

A NF-e deverá ser impressa em via única e entregue ao cliente e/ou, a seu pedido, ser enviada para o e-mail informado.

O Prestador deverá gerar no sistema o documento de arrecadação relativo às NF-e emitidas;

O recolhimento do imposto deve ocorrer até o dia 10 de cada mês relativamente às NF-e emitidas.

Após o recolhimento do ISS pelo Prestador será creditado, automaticamente, aos clientes, a parcela do imposto constante na NF-e.

O acompanhamento dos valores já creditados - e dos pendentes - pode ser feito pela internet.

Os valores creditados poderão ser utilizados para abatimento de até $50 \%$ do IPTU do exercício corrente e não há necessidade de qualquer vínculo entre o detentor do crédito e o imóvel indicado. Tanto o detentor do crédito quanto o imóvel indicado não podem constar do CADIN, na data da indicação.

\subsubsection{Programa de incentivo fiscal do Governo do Distrito Federal - Nota Legal}

O Governo do Distrito Federal criou o Programa Nota Legal em junho de 2008. A Lei no 4.159/08 foi regulamentada dois meses depois, tendo como inspiração o Nota Fiscal Paulista. O programa, porém, só engatou após a primeira campanha de divulgação, no segundo semestre de 2009. No ano passado, apenas $5 \%$ das 365.890 pessoas que, até então, tinham pedido a nota com CPF usaram os créditos. 


\subsubsection{Características do programa do programa Nota Legal}

O GDF é um ente da federação com características tributárias de Estado e de Município, logo a ele é permitido arrecadar receitas de tributos estaduais e municipais acumulando tanto o ICMS, quanto o ISS. Em média, temos alíquotas de ICMS de $17 \%$ e de $12 \%$ e ISS de $5 \%$ do valor de cada operação.

\subsubsection{Forma de estímulo para o contribuinte do programa Nota Legal}

Os benefícios da Nota Legal são cada vez mais conhecidos, embora alguns detalhes, como os critérios para o cálculo dos créditos em cada comprovante, ainda não sejam compreendidos pela maioria dos consumidores.

A legislação do Programa Nota Legal diz que até $7,5 \%$ da nota fiscal, quando se tratar de ICMS e até $1,5 \%$ da nota, quando for ISS, poderá virar crédito para o consumidor. Isso significa que $7,5 \%$ corresponde a $44 \%$ de todo o ICMS de uma operação a $17 \%$ e a $62,5 \%$ se a alíquota for $12 \%$. No caso do ISS, $1,5 \%$ corresponde a $30 \%$ da alíquota de $5 \%$ das prestações de serviços. Logo, os créditos do programa do GDF são muito melhores que os de São Paulo.

\subsubsection{Funcionamento do sistema do programa Nota Legal}

Em cada compra ou aquisição de serviços o consumidor informa o seu CPF/CNPJ e solicita sua Nota Fiscal ou Cupom Fiscal.

O vendedor registra o CPF/CNPJ do consumidor e emite a Nota Fiscal ou Cupom Fiscal, transmitindo a informação para a Secretaria de Fazenda por meio do Livro Fiscal Eletrônico no mês subsequente.

Após o efetivo recolhimento do ICMS ou do ISS pelo estabelecimento, a Secretaria de Fazenda creditará ao consumidor a parcela do imposto a que ele tem direito, proporcional ao valor da compra ou da aquisição do serviço.

O crédito poderá, dentro de dois anos, ser utilizado para reduzir o valor do lançamento do IPVA ou do IPTU, sem exigência de vínculo em relação ao proprietário do imóvel ou veículo indicado, desde que não haja débitos vencidos.

Segundo o blog Nota Legal, se uma empresa declara faturamento de $\mathrm{R} \$$ $100.000,00$ num certo mês e se todas as operações forem tributadas a $17 \%$ de ICMS gera $R \$ 17.000,00$ de imposto a ser recolhido. 
De acordo com a Lei 4.159/2008, art. 3ํㅡ, até 30\% do imposto recolhido se transformam em créditos para o Programa. Assim $R \$ 5.100,00$ (30\% de $R \$$ $17.000,00)$ serão partilhados entre aqueles que solicitaram o CPF na nota ou cupom fiscal.

Supondo que apenas uma pessoa solicitou a nota identificada, tendo gasto $R \$ 100,00$ na operação. Essa operação gerou apenas $R \$ 17,00$ para o GDF em ICMS. Obviamente, os $\mathrm{R} \$ 5.100$ não poderiam ir todo para o único consumidor que pediu a nota.

Por isso, em Dezembro de 2009, a lei foi alterada. Pelo texto anterior, precisava-se calcular o imposto devido de cada nota ou cupom fiscal, o que se mostrou inviável, embora fosse até mais justo. De fato, seria necessário que cada cupom fiscal tivesse seus itens discriminados uma a um, inclusive quanto ao percentual do imposto incidente, que pode variar de produto a produto. Mas essa discriminação ainda não é obrigatória no Livro Fiscal Eletrônico.

Então, para facilitar a conta dos créditos, foi introduzido um teto de $7,5 \%$ para ICMS e 1,5\% para ISS, mantendo a proporcionalidade com o valor da aquisição e não com o imposto devido em cada operação.

Assim, esse único consumidor receberá de crédito a proporção máxima: $R \$ 7,50(7,5 \%$ de $R \$ 100,00)$. E os demais $R \$ 5.092,50$ ficam para o GDF, que não é obrigado a partilhar esse crédito, porque ninguém mais pediu a nota identificada.

Mas, e se mais pessoas pedem a nota/cupom fiscal com identificação?

A partir de determinado percentual de identificação das notas, a proporção dos créditos diminui. Ou seja, para quem pede a nota identificada, o melhor é que nem todos as peçam, para que possamos ganhar o percentual de crédito máximo.

Por outro lado, se poucas pessoas solicitam o CPF/CNPJ no documento fiscal, menor é a chance de a empresa enviar o LFE corretamente, obrigando-nos a reclamar no site e depois entregar os originais.

Se poucos pedem, pouco será partilhado. O GDF não partilha essa diferença, devido ao baixo número de notas com identificação e a consequente aplicação do teto máximo de 7,5\% (ICMS) e 1,5\% (ISS).

Mas se houver um grande número de compras identificadas sem 0 correspondente lançamento do imposto, indica indício de sonegação. Neste caso, a empresa se veria obrigada a aumentar a declaração de vendas e, consequentemente, aumentar o recolhimento do imposto. Não é a toa que muitos 
dizem que o Programa dá prejuízo para o governo e vários e-mails falsos tentam enganar os consumidores com a ideia de quebra do sigilo fiscal do contribuinte. Então, ou o GDF consegue a adesão maciça dos consumidores, ou o Programa terá pouco êxito em aumentar a arrecadação. Por isso, havia a previsão do Programa distribuir prêmios para aumentar a base de compras identificadas.

Ao consumidor cabe fazer a parte mais fácil, pedir a nota fiscal. É verdade que ainda é mais vantajoso para a empresa não informar o total das vendas no livro fiscal. A multa pelo não envio da informação é fixa no valor de $R \$ 52,90$. Talvez se a multa fosse por porcentagem do faturamento, as empresas teriam mais um motivo em lançar no Livro Fiscal. Somente com o aumento da fiscalização por parte dos contribuintes ao pedir a nota com CPF e verificar o lançamento dentro do Programa o GDF alcançará seu objetivo. Pode ser que o governo acredite que mesmo com a baixa adesão dos consumidores já será suficiente para forçar as empresas a aumentarem a declaração de vendas. Isso significa que o GDF estima que a sonegação em alguns setores possa ser muito elevada. 


\section{A PESQUISA, O RESULTADO E DISCUSSÃO}

"Nada é certo nesse mundo exceto a morte e os impostos"20

A pesquisa de campo teve por finalidade avaliar o impacto do programa Nota Legal entre os possíveis usuários do programa. Ainda, aferir a sensibilidade do tema cidadania fiscal entre os contribuintes. A seguir serão apresentados os resultados da pesquisa.

\subsection{Metodologia}

A pesquisa teórico-bibliográfica teve maior concentração nos programas de diminuição e nos tributos envolvidos na operação.

A pesquisa de campo foi composta de um questionário, contendo oito questões objetivas e diretas. O questionário foi padronizado, com o objetivo de dar maior precisão no resultado da pesquisa.

O universo de pesquisa foi composto por pessoas com acesso a internet. Foram distribuídos convites por e-mail para alunos da Universidade de Brasília, Servidores da Presidência da República e ainda uma chamada para preenchimento no blog Nota Legal ${ }^{21}$.

A coleta de dados da pesquisa teve início no começo de março e se estendeu até o final de maio de 2011, perfazendo, aproximadamente, três meses de coleta.

Responderam o questionário 114 pessoas.

Foram realizadas análises estatísticas descritivas com os dados da pesquisa. Os resultados das análises serão a seguir demonstrados.

\subsection{Resultados e Discussões}

\subsubsection{Sexo dos pesquisados}

Dos 114 entrevistados que responderam ao questionário, 82 (72\%) eram do sexo masculino e $32(28 \%)$ eram do sexo feminino. Tal fato demonstra que ainda falta uma maior divulgação da temática tributária para o sexo feminino.

\footnotetext{
${ }^{20}$ Benjamin Franklin, cientista e político americano, $1706-1790$.

${ }^{21}$ http://notalegaldf.blogspot.com/
} 


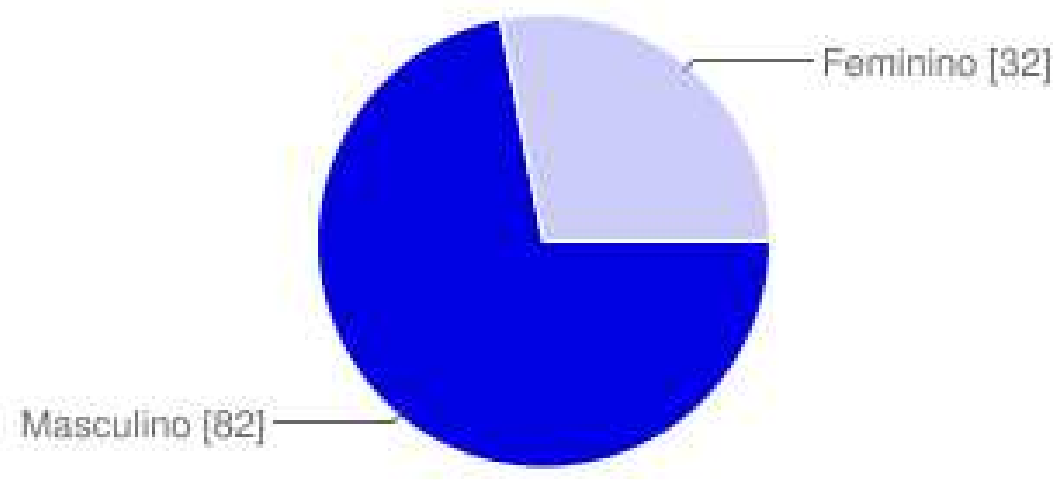

Figura 3 - Sexo dos entrevistados

\subsubsection{Grau de instrução dos pesquisados}

Quanto ao grau de instrução, 0 (0\%) dos entrevistados eram do nível fundamental, 13 (11\%) eram do nível médio, 55 (48\%) eram do nível superior e 46 (40\%) eram do nível pós-graduação, confirmando o elevado grau de instrução em Brasília. Esta estatística demonstra também que o programa tem maior uso quanto maior o nível de instrução, sendo necessário ao governo intensificar a propaganda do programa nas camadas mais baixas da população.

Este fato revela o grande erro do programa. Estatisticamente, quanto maior o nível de educação, maior a remuneração da pessoa e maior possibilidade de abatimento no imposto. A camada mais baixa da população não possui bens tributáveis pelo IPTU (imóveis) e IPVA (automóveis), diminuindo a capacidade de utilização do programa pelos mais atingidos pelos impostos indiretos e que sobre os quais incide proporcionalmente a maior carga tributária.

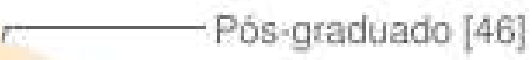

\section{- Nivel fundamental} Nivel médio [13]

\section{Superior [55]}

Figura 4 - Nível de instrução 
3.2.3 Nível de utilização do Programa Nota Legal

Quanto à utilização do programa, 96 (84\%) entrevistados utilizam e 18 (16\%) não utilizam o programa de incentivo. Tal fato demonstra o elevado grau de utilização.

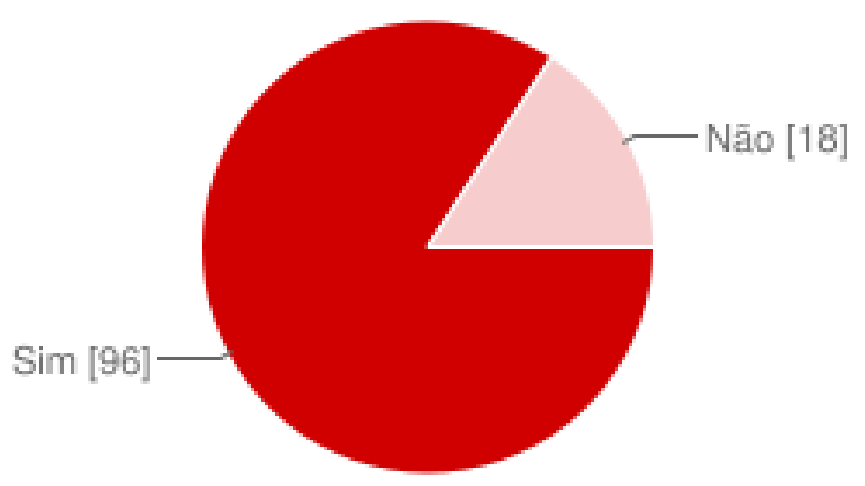

Figura 5 - Utilização do Programa

3.2.4 A possibilidade de quebra do sigilo fiscal ao fazer parte do Programa Nota Legal

Quanto à falsa ideia da possibilidade de quebra de sigilo por parte do fisco, 89 (78\%) pesquisados entendem que não há a quebra de sigilo e 23 (20\%) pesquisados, ainda, tem a impressão que o fisco distrital usa o programa para quebrar o sigilo fiscal dos contribuintes. É necessário aumentar a propaganda de utilização do sistema para convencer os $20 \%$ da população que entende como válida a quebra do sigilo.

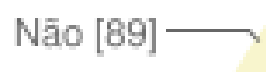

Figura 6 - Possibilidade de quebra de sigilo fiscal na utilização do programa 
3.2.5 Utilização de outros programas de incentivo

Quanto à utilização de outros programas de incentivo, como o Nota Paulista e o Nota Paulistana, 74 (65\%) pesquisados afirmaram não utilizar outros programas e $38(33 \%)$ utilizam, o que demonstra o alcance da propaganda dos outros Estados da Federação e a necessidade da busca pela diminuição da carga tributária por parte dos contribuintes.

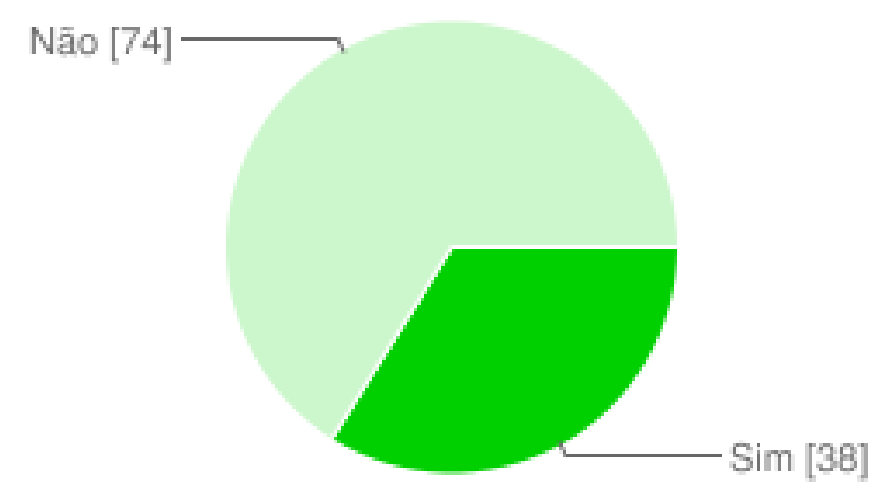

Figura 7 - Utilização de outros programas de incentivo

\subsubsection{Motivo de utilização do programa}

Quanto ao motivo de utilização do programa, 58 (51\%) pesquisados afirmaram que o motivo de utilização do programa é a diminuição das despesas tributárias. $38(33 \%)$ pesquisados afirmaram que utilizam o programa para diminuir as despesas tributárias e para auxiliar na arrecadação de impostos. Nenhum pesquisado afirmou que pensa em auxiliar a fiscalização tributária e na arrecadação de impostos, o que tende a demonstrar que a população está sobrecarregada de tributos deixando de lado a cidadania fiscal.

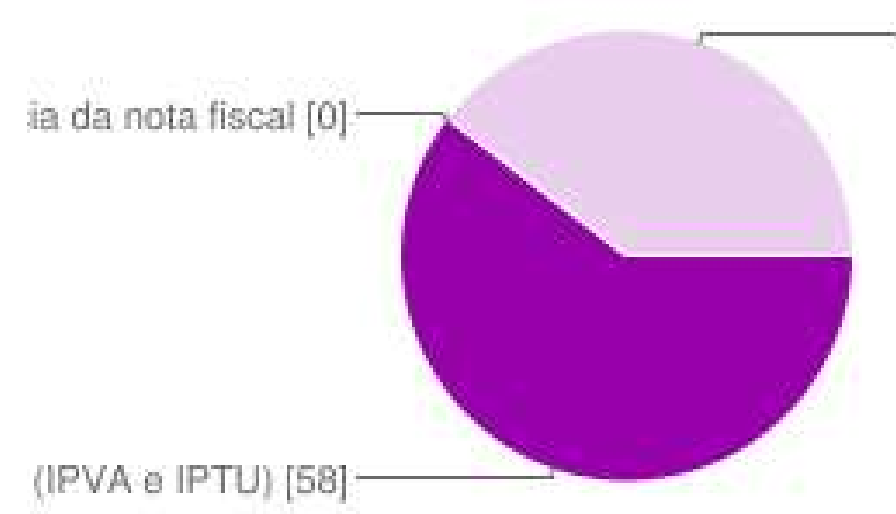

Figura 8 - Motivo de utilização do programa

3.2.7 Facilidade de compreensão e uso do programa 
Quanto ao tema facilidade de compreensão e uso do programa, 72 (63\%) pesquisados afirmaram que o programa é de fácil uso e compreensão e 31 (27\%) o acharam de difícil uso. Tal fato demonstra que o programa ainda possui um longo caminho para sua universalização. Quase um terço dos pesquisados considera o programa de difícil uso, um número alto para os benefícios do programa.

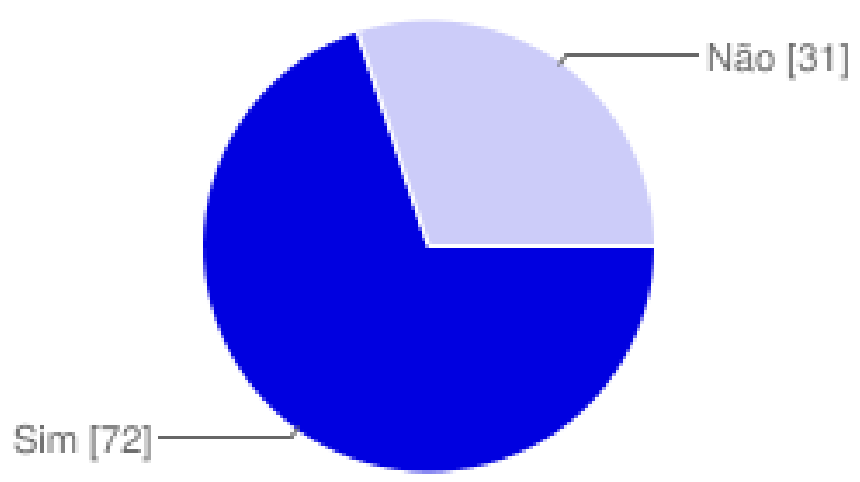

Figura 9 - Facilidade de uso e compreensão

3.2.8 Maior exigência em pedir a nota fiscal nas compras

Quanto ao se tornar mais exigente na solicitação da nota fiscal, 92 (81\%) pesquisados aumentaram o nível de exigência na hora das compras e 16 (14\%) ainda não pedem nota fiscal. Neste sentido o programa alcançou seu maior objetivo, aumentar o conhecimento do contribuinte e a necessidade de se pedir a nota fiscal.

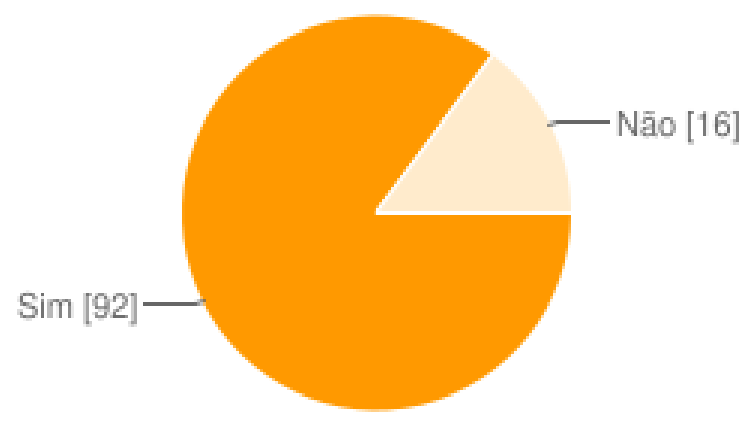

Figura 10 - Nível de exigência de nota fiscal após utilização do programa 


\section{CONSIDERAÇÕES FINAIS}

A grande maioria da população desconhece a elevada tributação a que é submetida. Programas de incentivo cumprem com a finalidade de mostrar aos cidadãos como diminuir sua carga tributária ao mesmo tempo em que desperta nele o gosto pelo estudo dos tributos.

Os programas de incentivo não podem ser um fim em si mesmo. A implantação foi realizada com a finalidade de aumentar o controle fiscalizatório, informatizar o sistema, aumentar a arrecadação, dividir a fiscalização com o cidadão e reduzir a carga tributária.

O programa Nota legal não atinge a camada mais pobre da sociedade. $O$ abatimento no IPTU e IPVA pressupõe ter o cidadão um patrimônio a ser tributado. O modelo paulista melhor se adapta ao possibilitar a retirada em dinheiro, dos créditos concedidos pelo programa.

Ainda, a maturação do sistema fará com que haja a diminuição do poder arrecadatório, não resolvendo o maior problema do contribuinte.

Como equilibrar a equação arrecadação versus despesas necessárias para o funcionamento do estado? É sabido que a população já não aumenta mais a voracidade arrecadatória que retira mais de $30 \%$ do PIB de circulação para manter um organismo pesado e ineficiente.

Um pacto federativo que reveja as responsabilidades tributárias pode ser uma solução. Os programas apenas tratam da doença, mas não buscam eliminar a causa. A enorme quantidade de leis tributárias exige setores específicos nas empresas para o planejamento tributário. Simplificar o sistema é indispensável.

Mas nem tudo está perdido. No dia 01 de julho de 2011, a Câmara Legislativa do Distrito Federal aprovou um projeto de lei para que o benefício seja ampliado a toda a população do Distrito Federal, por meio do depósito em conta bancária, e não apenas garanta desconto para quem paga o Imposto Predial e Territorial Urbano e o Imposto sobre a Propriedade de Veículos Automotores. A proposta passou pelo crivo dos parlamentares às pressas, antes do recesso de julho. Para entrar em vigor, é preciso que o texto receba a sanção do governador Agnelo Queiroz. Por enquanto, o documento passa pela análise da consultoria jurídica e não há prazo para que seja concluída. 
Mas ainda é necessário diminuir as obrigações tributárias, para que não se venda facilidades, aumentar a transparência e traduzir em eficiência os recursos arrecadados.

Percebe-se que os programas alcançaram um outro objetivo. Eles propiciaram o aumento da cidadania fiscal do cidadão por meio da descoberta do funcionamento do sistema tributário brasileiro.

Por fim, pode-se inferir pela pesquisa realizada que o cidadão busca diminuir sua carga tributária. O contribuinte não agüenta mais! 


\section{REFERÊNCIAS}

BARBOSA, ALICE MOUZINHO. Cidadania Fiscal. Curitiba: Juruá, 2005.

CARDIN, DIRCEU GALDINO. Desafios da Cidadania. Brasília: OAB, 2006.

DALARI, D. Direitos Humanos e Cidadania. 2. ed. São Paulo: Moderna, 2004

GODOY, WALTER. Os Direitos dos Contribuintes. $2^{\underline{a}}$ ed. Porto Alegre: Síntese, 2003.

ISKANDAR, JAMIL IBRAHIM. Normas da ABNT Comentadas para Trabalhos Científicos. 4aa ed. Curitiba: Juruá, 2011.

MELO, JOSÉ EDUARDO SOARES DE. Curso de Direito Tributário. 9a ed. São Paulo: Dialética, 2010

MOREIRA, MARGARETE IARA FRANCO. Cidadania Fiscal: a percepção dos alunos do 9 ano do ensino fundamental de uma escola pública e outra particular, de Campo Grande - MS. Brasília, 2010.

PAUSEN, LEANDRO. Direito Tributário: Constituição e Código tributário à Luz da doutrina e da jurisprudência. 12 ed. Porto Alegre, 2010

POCHMAN, Márcio.Desigualdade e Justiça Tributária. Brasília: IPEA, 2008.

TORRES, Ricardo Lobo. Sistemas Constitucionais Tributários. $1^{\underline{a}}$ ed. Rio de Janeiro: Forense, 1986.

VIVES, MARIA LUISA. Educación Tributaria, Un enfoque integral. Buenos Aires: Ad-Hoc, 2005.

$<$ HTTP: http://notalegaldf.blogspot.com/> 


\section{ANEXO A - QUESTIONÁRIO APLICADO AOS POSSÍVEIS USUÁRIOS DO PROGRAMA NOTA LEGAL}

\section{Cidadania fiscal e o Programa Nota Legal do DF}

Olá! Estou quase terminando meu curso de Direito da Universidade de Brasília. Peço sua singela contribuição para tornar possível minha graduação. Meu campo de pesquisa é o direito tributário e cidadania fiscal e a minha monografia de conclusão de curso tem por finalidade estudar o perfil dos usuários do Programa Nota Legal do Distrito Federal. Não se preocupe, sua resposta será tratada com o devido sigilo e não há a identificação do usuário. Por fim, sua colaboração será de extrema importância. Muito Obrigado.

Qual o seu sexo?

( )Masculino

( )Feminino

Qual o seu grau de instrução?

( )Nível fundamental

( ) Nível médio

( ) Superior

( ) Pós-graduado

O Sr(a) Utiliza o Programa Nota Legal?

( ) Sim

( )Não

- Sr(a) entende como válida a afirmação: o programa também serve também para quebrar meu sigilo fiscal, o que pode me trazer problemas com o fisco.

( ) Sim

( )Não

O Sr(a) utiliza outro programa de incentivo como o Nota Paulista do Estado de São Paulo ou o Nota Carioca do Rio de Janeiro?

( ) Sim

( )Não 
Caso o utilize, qual o motivo de utilização do Programa Nota Legal?

( ) Diminuição das despesas tributárias (IPVA e IPTU)

( ) Auxiliar na fiscalização tributária e na arrecadação de impostos por meio da exigência da nota fiscal

( ) Diminuir as despesas tributárias e auxiliar na fiscalização e na arrecadação de impostos.

Caso o utilize, o programa é de fácil compreensão e uso?

( ) Sim

O Sr(a) se tornou mais exigente na solicitação da nota fiscal após o cadastramento do programa?

( ) $\operatorname{Sim}$

( ) Não 


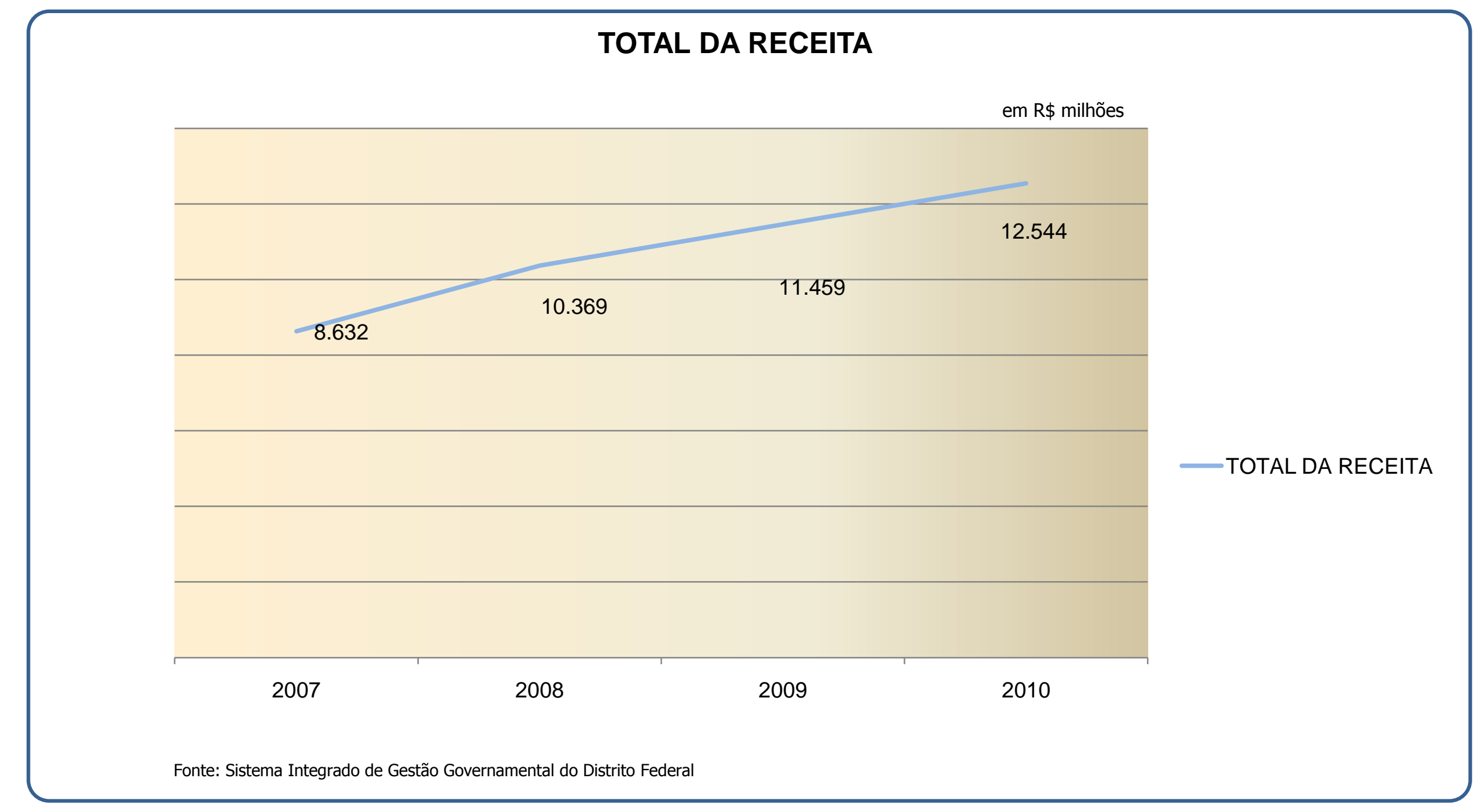




\section{TOTAL DA RECEITA x RECEITAS TRIBUTÁRIAS}

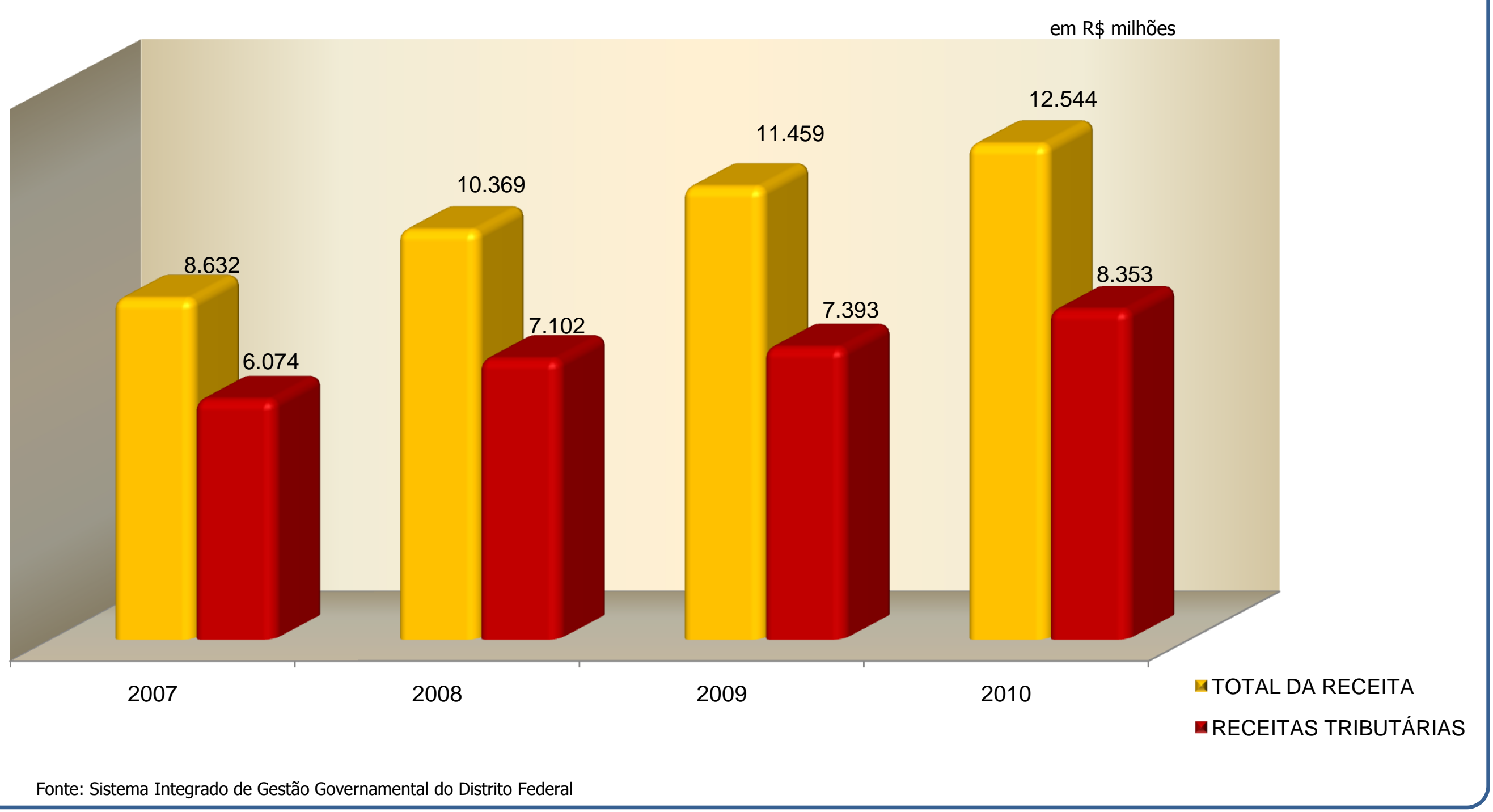

